\title{
Flaws in the Spanish Translation of Beginning Readers' Books ${ }^{1}$
}

\section{(Deficiencias en la traducción al español de libros de lectura inicial)}

Sonia Rodríguez Salazar ${ }^{2}$

Universidad Nacional, Costa Rica

\begin{abstract}
This article presents the main results of an analysis of important flaws in the Spanish translation of a number of children's story books, known as Beginning Readers' Books. It addresses errors which can affect the children's process of acquiring reading and writing skills. These deficiencies can be attributed to the translators' lack of familiarity with the initial reading patterns and their relation to a phonological awareness of Spanish. This study aims to provide initial guidelines for a translation of this sort.
\end{abstract}

\section{resumen}

Se exponen los principales resultados de un estudio que analiza significativas deficiencias en la traducción al español de varios tomos de cuentos, bajo el título general de Beginning Readers' Books. Se trata de errores que afectan el proceso de lectoescritura del lector meta. Tales deficiencias se atribuyen al desconocimiento de patrones básicos de lectura y su relación con la conciencia fonológica del español. El estudio tiene como objetivo ofrecer una guía inicial para mejorar este tipo de traducciones.

Keywords: translation, children's literature, reading/writing process

Palabras clave: traducción, literatura infantil, proceso de lectoescritura

1 Recibido: 26 de enero de 2014; aceptado: 25 de agosto de 2014. Elaborado a partir de la ponencia presentada por la autora en el IV Congreso Internacional de Lingüística Aplicada, llevado a cabo en 2013, en el Campus Omar Dengo, de la Universidad Nacional de Costa Rica.

2 Escuela de Literatura y Ciencias del Lenguaje. Correo electrónico: sonia.rodriguez.salazar@una.cr 


\section{Introduction}

The study of the translation of children's literature has covered many issues related to intercultural ideologies, visual and verbal aspects, intertextuality, and the background of the specialty itself. ${ }^{3}$ However, the role of children's books for the development of the reading and writing skills has yet to be analyzed exhaustively for translation purposes.

In the national context, Meghan Posey's "Advantages of L2 Translation in The Cat in the Hat: A Closer Look at Translation Directionality"4 addressed the topic, but emphasized the value of indirect translation. On the other hand, Cindy Rodríguez ${ }^{5}$ researched the translation of children's literature, focusing on adjective translation norms. Thus, the role played by Beginning Readers' Books (known as readers) as shapers of language development needs urgent attention. In Costa Rica, the Spanish version of many of these readers aimed at 6 or 7 year-old primary school children does not comply with the function of language development for they were created. That is, readers should help primary students develop independent reading. The decoding stage begins at this level as a basis for reaching higher levels of comprehension later. If a child does not decode well at the beginning, frustration and disappointment would probably inhibit novice young readers. ${ }^{6}$

The purpose of this presentation is to examine the main results of an extensive study ${ }^{7}$ which shows how relevant it is for translators

3 Gillian Lathey, The Role of Translators in Children's Literature: Invisible Storyteller (Londres: Routledge, 2010); The Translation of Children's Literature: A Reader (Clevedon, UK: Multilingual Matters, 2006).

4 Letras 46 (2011): 87-100.

5 Cindy Rodríguez, Normas de traducción de los adjetivos calificativos en la literatura infantil (Heredia: Universidad Nacional, 2010).

6 Jessica Araya, «La valoración del componente fonológico en niños que inician el proceso de lectoescritura». Kañina. Rev. Artes y Letras 33.2 (2009): 36. Web. 3 June 2011.

7 Sonia Rodríguez Salazar, Consideraciones linguístico-didácticas para la traducción directa de cuentos infantiles utilizados para desarrollar la lectoescritura en estudiantes de la etapa de transición y primer grado (trabajo de graduación) (Heredia: Universidad Nacional, 2012). 
to be familiar with the syllabic patterns of both languages, and with what the reading process consists of in each case, as a basis for the lexical choices they have to make when translating children's stories and books with didactic purposes.

\section{Literature Review}

To fully comprehend the importance of the reading process, Araya ${ }^{8}$ defines the acquisition of reading and writing skills as necessary complex activities that shape a culture and underlines the importance of the phonemic awareness, since this early skill facilitates decoding or word recognition (lexical level) and comprehension. Tabash ${ }^{9}$ adds that teachers have to understand that reading comprehension should always be present since the beginning levels, this being a condition for children to enjoy reading. In the translation field, author and translator of children's literature Tiina Puurtinen ${ }^{10}$ states that ahard-to-read story will likely slow down young readers' interest and as a consequence, their reading skill development falls behind.

If one takes into account that a text fulfills an objective or function, then its translation into Spanish has to correspond to that function as well. In this regard, in systematic historical research on contemporary translation theories, Virgilio Moya ${ }^{11}$ points out how Eugene Nida, Reiss and Vermeer, and Christiane Nord have each supported the idea of the functionalist approaches in translation, each from a different perspective, yet seeking the same objective. According to Moya (47), Nida states that both sense and function in the source text (ST) has to be equivalent to that of the translated text (TT). By the

\footnotetext{
$8 \quad$ Araya, $35-36$

9 Nayibe Tabash, "La lectura interactiva en el desarrollo de las habilidades de comprensión de lectura y de expresión escrita." Revista de Lenguas Modernas: 12 (2010): 221.

10 Tiina Puurtinen, "Syntax, Readability and Ideology in Children's Literature," Meta: journal des traducteurs / Meta: Translators' Journal. 43.3 (1998): 2. Web. 12 October 2011.

11 Virgilio Moya, La selva de la traducción. Teorías traductológicas contemporáneas (Madrid: Cátedra, 2004): 47-89.
} 
end of the 1970s and during the 1980s, on the other hand, Reiss and Vermeer ${ }^{12}$ extended idea of the goal or function of the TT, stating that this objective may not be similar to that of the ST. The Skopostheorie, or skopos (Greek for aim or objective), emphasizes the goal of the TT in order to obtain a more appropriate rendering of this TT. Later, Nord ${ }^{13}$ further develops the functionalist approach by adding more value to the initiator, the person or client from the translator's point of view, as defined by the same author. The initiator points out in the translation brief the final purpose of the TT. In sum, each of these theorists contributed to the enhancement of the functionalist approach, which seems appropriate for the type of translation that a children's book or story requires. That is, this particular TT has to comply with the function of developing a child's reading skills in the same way as they are developed with the ST.

A translator can use different techniques within the adaptation strategy. Fortranslator and professor IsabelPascuaFebles, ${ }^{14}$ adaptation is seen as a non-equivalent bilingual activity opposing translation per $s e$.Adaptation can be applied when there is no correspondence between cultures in the L1 and L2, or in the T1 and T2, when language norms do not coincide, rendering as a consequence, an acceptable TT which is also equivalent to the ST at the communicative level. Therefore, adaptation would be any change in the semantic structure of the TT provided that the variation is justified by the reasons mentioned above.

Pascua ${ }^{15}$ classifies adaptation in three categories: compulsory, admissible and inadmissible adaptations. Compulsory adaptations are made when the TT does not conform to communicative equivalence (phrase coined by Isabel Pascua) and variations have to be made to

\footnotetext{
12 Moya, 88 .

13 Christiane Nord, Translating as a Purposeful Activity. Functionalist Approaches Explained (Manchester, UK: St. Jerome, 1997) 58.

14 Isabel Pascua Febles, La adaptación en la traducción de la literatura infantil (Las Palmas de gran Canaria: Universidad de Las Palmas de Gran Canaria. Servicio de publicaciones, 1998) 40-43. Web. 25 May 2012.

15 Pascua, 43.
} 
meet this purpose. These changes can be made through omission, explicitation or addition, and substitutions. Admissible adaptations correspond to those multiple options that translators have; they do not oppose the original ST and the communicative equivalence is not violated. Finally, inadmissible adaptations refer to those changes that do not comply with any of the required conditions above.

\section{Methodology}

A specific parallel corpus of children's literature (readers), in English and in Spanish, was selected for comparison, with all books intended to be used wth 6 to 7 year-old children, in general beginning reading stages in the Costa Rican educational system. The corpus study compared twenty-one Readers which had been translated into Spanish with their corresponding original texts in English. It focused on the lexical level due to the relevance these units of thought have in the development of the reading process. These lexical observations sought to identify compliance with the phonemic awareness reading patterns for the level that the books were intended for.

As a result of this comparison, more than a hundred words are considered "flaws" in the TTs since these lexical units do not meet the appropriate reading level for the age target audience. Examples are explained and total of errors are quantified in the following sections.

\section{Results}

Aside from Jessica Araya and Tiina Puurtinen, other professionals ${ }^{16}$ in the fields of education and translation stress the importance of readability and describe the different syllabic patterns of English and

16 Luz Adriana Forero and Rosalía Montealegre, "Desarrollo de la lectoescritura: adquisición y dominio," Acta Colombiana de Psicología 9.1 (2006): 25-40. Web. 17 April 2012; Ana Chaves, "Los procesos iniciales de lectoescritura en el nivel de educación inicial." Actualidades Investigativas en Educación. 2.1 (2002): 1-23. Web; Lawrence E. Hafner and Hayden B. Jolly, Patterns of Teaching Reading in the Elementary School (New York: Macmillan, 1971). 
Spanish. Therefore, one of the most crucial findings of the completed study shows that the phonemic awareness patterns (forming lexical units) in these languages are not entirely similar for their language acquisition norms differ. As obvious as this may seem, this knowledge is a turning point in the work a translator does at the lexical level. Hence, when primary schoolers in both cultures are learning to read, they are taught according to the patterns shown in Table 1.

\section{Table 1. Reading patterns for phonemic awareness in Spanish and English}

\begin{tabular}{|l|l|}
\hline \multicolumn{1}{|c|}{ Spanish } & \multicolumn{1}{c|}{ English } \\
\hline CV & CVC \\
\hline CCV & CVC-e \\
\hline \multirow{2}{*}{-} & CC consonant blends $(s t, b l)$ \\
\cline { 2 - 2 } & CC consonant digraphs $(c h, w h)$ \\
\hline CCVC & CVVC \\
\hline
\end{tabular}

$\mathrm{C}=$ consonant; $\mathrm{V}=$ vowel

Table 1 shows the structure of phonemic awareness acquisition that a reader is taught in the beginning stages of reading in Spanish; emphasis needs to be given to phonemes and syllables. In English a similar way of teaching reading uses a simple to complex spelling pattern regardless of the reading method chosen. Example words of the Spanish patterns are simple syllables: $m a$, se, $p i$; and complex consonant groups such as bra, fle, cro or tran and bron. In English, words such as pat, bat, hop; hope, same, time; rain, coat, and seem, are examples of the consonant-vowel patterns illustrated above. Nevertheless, none of the patterns are alike in any combination of syllables.

Once novice readers master these phases in the reading process, they can be exposed to complex words and longer units of thought such as multisyllabic words and then sentences. These levels are beyond the scope of this study. 
The four comparative tables are provided below from the twenty-one books analyzed in the extended study. The comparison shows several excerpts from the original English books and the Spanish versions. Comparative tables 2, 3, 4, and 5 reveal the flaws found after the corpus analysis was completed, where the words chosen in Spanish do not have an adequate level of difficulty for the initial stages of the reading acquisition process.

\section{Table 2. Comparison of Clifford the Champion ${ }^{a}$ and Clifford el campeón ${ }^{b}$}

\begin{tabular}{|c|c|c|}
\hline \multicolumn{3}{|c|}{ Level 1 (32 pages) } \\
\hline Original Excerpts ${ }^{\mathrm{a}}$ & Spanish Translation $^{b}$ & Possible Substitutions \\
\hline $\begin{array}{l}\text { The winner would be } \\
\text { America's Super Dog } \\
\text { and get a prize. }\end{array}$ & $\begin{array}{l}\text { El ganador se convertiría } \\
\text { en el Mejor Perro de Amé- } \\
\text { rica y obtendría un trofeo. }\end{array}$ & $\begin{array}{l}\text { Sería } \\
\text { gana }\end{array}$ \\
\hline $\begin{array}{l}\text { The judges told us to join } \\
\text { the other large dogs. }\end{array}$ & $\begin{array}{l}\text { Los jueces nos dijeron } \\
\text { que siguiéramos a los } \\
\text { otros perros grandes. }\end{array}$ & ...nos enviaron con... \\
\hline $\begin{array}{l}\text { Champ got } 10 \text { points. } \\
\text { Clifford got } 4 \text {. }\end{array}$ & $\begin{array}{l}\text { Champ obtuvo } 10 \text { pun- } \\
\text { tos. Clifford obtuvo } 4 .\end{array}$ & ganó \\
\hline Next the dogs had to leap... & $\begin{array}{l}\text { A continuación, los pe- } \\
\text { rros tenían que saltar... }\end{array}$ & Luego, ... \\
\hline It was easy for Champ. & $\begin{array}{l}\text { Champ completó la prue- } \\
\text { ba fácilmente. }\end{array}$ & $\begin{array}{l}\text { Fue fácil para Champ } \\
\text { terminar la carrera. }\end{array}$ \\
\hline $\begin{array}{l}\text { But not for Clifford. } \\
\text { Champ got } 25 \text { more points. }\end{array}$ & $\begin{array}{l}\text { Clifford tuvo dificultades. } \\
\text { Champ obtuvo } 25 \text { puntos. }\end{array}$ & $\begin{array}{l}\text { No fue así para Clifford. } \\
\text { Champ ganó } 25 \text { puntos. }\end{array}$ \\
\hline $\begin{array}{l}\text { The dogs had to chase it } \\
\text { and jump high to catch it. }\end{array}$ & $\begin{array}{l}\text { Los perros debían perseguir- } \\
\text { lo y saltar para agarrarlo. }\end{array}$ & $\begin{array}{l}\text { Los perros lo buscaban y } \\
\text { saltaban para tomarlo. }\end{array}$ \\
\hline
\end{tabular}

${ }^{a}$ Norman Bridwell, Clifford the Champion (Nueva York: Scholastic, 2009).

${ }^{\mathrm{b}}$ Bridwell, Clifford el campeón (Nueva York: Scholastic, 2010).

Comparative table 2 shows the use of initial reading patterns in the source text; and although the Spanish version conveyed the meaning for an adult reader, it failed to use the level of spelling that initial 
readers require for independent reading and subsequent comprehension. The Spanish words had complex and multiple syllables, which as discussed above, are not suitable for the target readers.

Some tales showed both unsuccessful and successful lexical choices as seen in the comparative tables 3 and 4, in which the translator chose appropriate level words. What it is not known is whether this selection was made consciously.

\section{Table 3. Books: Biscuit Finds a Friend ${ }^{a}$ / Bizcocho encuentra un amigo ${ }^{b}$}

\begin{tabular}{|l|l|l|}
\hline \multicolumn{3}{|c|}{ Level: My First Reading (25 pages) } \\
\hline \multicolumn{1}{|c|}{ Original Excerpts } & Spanish Translation & \multicolumn{1}{|c|}{ Possible Substitutions } \\
\hline What has Biscuit found? (5) & $\begin{array}{l}\text { ¿Qué ha } \text { encontrado } \\
\text { Bizcocho? (5) }\end{array}$ & Visto, vio \\
& $\begin{array}{l}\text { Llevaremos al patito de } \\
\text { vuelta al estanque (10). ... la laguna }\end{array}$ \\
$\begin{array}{l}\text { We will bring the little } \\
\text { duck back to the pond (10). }\end{array}$ \\
\hline Examples of Appropriate Translation \\
\hline Time to go home, Biscuit (21). & Es hora de volver Bizcocho (21). \\
\hline
\end{tabular}

${ }^{a}$ Alyssa S. Capucilli, Biscuit Finds a Friend (New York: Harper Collins Publishers, 1997). ${ }^{\mathrm{b}}$ Capucilli, Bizcocho encuentra un amigo, Trad. Susana Pasternac (New York: Harper Collins Publishers, 1997).

Comparative table 3 includes an example of a successful translation excerpt showing that some of the books did embrace the function of the reading book at times. The translator could have chosen the word regresar for the verb to go; instead, an appropriate word for the level, volver, was selected, with a simpler syllabic combination. Similarly, table 4 illustrates another reader with successful word choices. 


\section{Table 4. Books: Curious George Cleans Up / Jorge el curiosos limpia el reguero ${ }^{a}$}

\begin{tabular}{|l|l|l|}
\hline \multicolumn{3}{|c|}{ Level 1 (24 pages) } \\
\hline \multicolumn{1}{|c|}{ Original Excerpts } & \multicolumn{1}{|c|}{ Spanish Translation } & Possible Substitutions \\
\hline $\begin{array}{l}\text { And he had to } \text { get } \text { help } \\
\text { towing it home (17). }\end{array}$ & $\begin{array}{l}\text { Y tuvo que conseguir } \\
\text { ayuda para trasladarla a } \\
\text { la casa (17). }\end{array}$ & $\begin{array}{l}\text { Y buscó ayuda para } \\
\text { llevarla a la casa. }\end{array}$ \\
\hline Examples of Appropriate Translation \\
\hline All that walking made George thirsty(6). & Con tanta actividad, a Jorge le dio sed (6). \\
He used the pump a long time (18). & Bombeó el agua por un buen rato (18). \\
\hline
\end{tabular}

${ }^{a}$ Stephen Krensky, Curious George Cleans Up/Jorge el curioso limpia el reguero: libro bilinguüe en español e inglés. Trad. Yanitzia Canetti (Boston: Houghton Mifflin, 2007).

The vocabulary in the original books is a reliable first sign for a translator. The level of words used is a guide for appropriate choices during the translation process, to prevent flaws such as the ones seen in comparative table 5 .

Table 5. Books: The Mystery of the Cheese ${ }^{a}$ / El misterio del queso ${ }^{b}$

\begin{tabular}{|l|l|l|}
\hline \multicolumn{3}{|c|}{ Level 3 (32 pages) } \\
\hline \multicolumn{1}{|c|}{ Original Excerpts } & \multicolumn{1}{|c|}{ Spanish Translation } & Possible Substitutions \\
\hline "Help me get it (13)." & Ayúdame a alcanzarlo (13). & Tomarlo \\
So, he went home and & $\begin{array}{l}\text { Así que volvió a su casa y } \\
\text { consiguió un bote (25). }\end{array}$ & tomó \\
got a boat (25). & $\begin{array}{l}\text { Persiguieron el queso por } \\
\text { They chased the cheese } \\
\text { all over the water (26). }\end{array}$ & Buscaron agua (26). \\
\hline
\end{tabular}

a Paul Harrison, The Mystery of the Cheese (Columbus: Children's Publishing, 2004).

${ }^{\text {b } H a r r i s o n, ~ E l ~ m i s t e r i o ~ d e l ~ q u e s o ~(C o l u m b u s: ~ C h i l d r e n ' s ~ P u b l i s h i n g, ~ 2004) . ~}$

In table 5 the verb get in English may seem simple to the experienced eye; it is also a convenient way of expressing a number of ideas in the language. Nonetheless, the simplicity in the spelling pattern of this word indicates the need to find words with similar characteristics 
in Spanish. A lack of creativity or knowledge during the translation process can cause negative experiences for beginning readers, as illustrated here in the change from got to consiguió.

\section{Discussion}

The corpus of the study reveals that each of the twenty-one texts analyzed contains vocabulary requiring change to comply with the didactic function of the story books. There were 129 flaws of this type found in the 439 pages analyzed. In other words, $30 \%$ of the vocabulary contains translation flaws in the corpus of the readers. Due to the nature of the readers, every page contains a sentence or complete idea, and if there is a difficult word to read in each idea or on every page, the sentence may be difficult to read and consequently comprehension fails from the perspective of the beginning reader; thus, the reading objective is not fulfilled. The percentage of flaws discovered is a warning for translators; for this reason, a customized checklist has been developed to edit translated texts. Table 6 shows a prototype checklist for the type of text studied.

Table 6. Editing Checklist for the Translation of Readers

\begin{tabular}{|c|c|}
\hline 1 & \\
\hline $\begin{array}{l}\text { glish Readers } \\
\text { old Pupils }\end{array}$ & $\begin{array}{l}\text { Lexical F } \\
\text { ers Intend }\end{array}$ \\
\hline $\begin{array}{l}\text { Syllabic patterns (consonant-vowel } \\
\text { ombination) }\end{array}$ & $\begin{array}{l}\text { itterns (consonant-vowel } \\
\text { n) }\end{array}$ \\
\hline & \\
\hline Ce & \\
\hline CC: sh, th, wh, gh (cor & \\
\hline $\begin{array}{l}\text { CVC-e: dime, mine } \\
\text { CVVC: rain, coat }\end{array}$ & $\begin{array}{l}\text { - CCVC: tran, bron (complex } \\
\text { group 2) }\end{array}$ \\
\hline
\end{tabular}




\begin{tabular}{|l|l|c|}
\hline 6 (b) Checklist & V \\
\hline $\begin{array}{l}\text { Potential problems when } \\
\text { translating into Spanish }\end{array}$ & Strategies & \\
\hline $\begin{array}{l}\text { Syllabic patterns in } \\
\text { English and Spanish }\end{array}$ & $\begin{array}{l}\text { Choose words in Spanish preferably in the } \\
\text { order given in this list: } \\
\text { 1. Simple syllables (ca, go, ru) } \\
\text { 2. Complex consonant clusters 1 (cre, gro, etc.) } \\
\text { 3. Complex consonantclusters2 (tran, bron, etc.) } \\
\text { 4.Choose multiple-syllable words (3+) if } \\
\text { made up of simple syllables. }\end{array}$ & \\
\hline
\end{tabular}

The checklist in table 6 begins with a brief summary (section 6 (a)), of syllabic patterns for phonemic awareness acquisition in both languages as a quick reference for the busy translator, and the second section (6 (b)), includes the checklist itself with problematical cases encountered in the readers. These strategies are based on the extensive observation of the comparable corpus used for this study.

\section{Conclusions}

The corpus analyzed illustrates common flaws translators might make during the translation of Beginning Readers' Books. The words in the comparative tables above have failed to have the syllabic patterns given in table 1 . Knowledge of the acquisition of the reading and writing process in Spanish, and specifically regarding the syllabic patterns and phonemic awareness, can enable the translator to select words which are more appropriate for the given level.

As a language level indicator, translators can look at the type of vocabulary and syllabic patterns followed in readers in English. This observation provides a guide to the ST level. With this in mind, the translator can seek to attain the appropriate corresponding level of the TT with the corresponding initial syllabic patterns for the target readers in Spanish. Thus the didactic function and communicative equivalence in the target culture can be accomplished. 
This study also reveals that flaws concerning lexical choice in Spanish are due to possible faithful and literal translation of the ST. Meaning prevailed more than the pedagogical component in the story book. However, both aspects can be attained with the adaptation strategies suggested.

Equally important it is to state that the simplicity of this type of books can be illusory and make the translator overlook the complexity of an actually challenging task. For this reason, the suggested checklist aims at supporting the language professional in the editing process. One future issue to be added to this checklist could be related to Spanish syntax which tends to become a linguistic borrowing from English in this kind of texts, thus undermining the language model children's literature plays.

Translators are encouraged to create and implement editing checklists due to the added value they give to the profession. Checklists assist the busy independent translator, coordinators who design desk copies, and editors and publishers to maintain quality standards. 